\title{
CONFIDENCE ANALYSIS AND CALIBRATION OF A FC-28 SOIL MOISTURE SENSOR MOUNTED ON A MICROCONTROLLER PLATFORM
}

\author{
Fernando Ferreira Lima dos SANTOS ${ }^{*}$, Leticia Cardoso Madureira TAVARES ${ }^{1}$, Guilherme de Moura \\ ARAÚJO2 ${ }^{2}$, Lucas de Lima Casseres dos SANTOS ${ }^{1}$, Caio Picinin Rocha Affonso NOGUEIRA ${ }^{3}$, \\ Matheus Santos BACHINI ${ }^{3}$, Marcos Alexandre TEIXEIRA ${ }^{3}$
}

\author{
1Departamento de Engenharia Agrícola, Universidade Federal de Viçosa, Viçosa, MG, Brasil. \\ ${ }^{2}$ Department of Biological and Agricultural Engineering, University of California, Davis, CA, United States. \\ 3Departamento de Engenharia Agrícola e Ambiental, Universidade Federal Fluminense, Niterói, RJ, Brasil. \\ *E-mail: fernando.flsantos@gmail.com \\ (ORCID: 0000-0002-0946-6005; 0000-0002-5028-0931; 0000-0002-3846-9387; 0000-0002-2959-0062; \\ 0000-0002-1769-6863; 0000-0001-6359-0560; 0000-0003-2604-6616)
}

\begin{abstract}
Recebido em 30/09/2019; Aceito em 08/02/2021; Publicado em 25/02/2021.
ABSTRACT: Nowadays, the global water crisis poses a great challenge to humanity and a risk to be managed by future generations. In order to use this resource consciously, it is known in the area of agricultural irrigation the need to evaluate the amount of water to be used. Among the soil moisture content determination methods, sensors, coupled to a programmable logic controller, emerge as an alternative to conventional laboratory methods, making the procedure faster and less labor intensive. In this sense, the present work aimed to evaluate the reliability and precision of a low-cost sensor to determine soil moisture content. It was concluded that the evaluated sensors did not present a known precision to estimate the level of soil moisture content. A FC-28 sensor coupled with a Arduino platform was used with three different soils (texture: low, medium and heavy), moisture ranging from 15 to $50 \%$. The results indicated that soil texture influenced the readings, even at the same humidity. In addition, the evaluated sensors did not present replicability nor accuracy for less them $10 \%$ moisture differences. Therefore, there is need to calibrate each sensor individually.
\end{abstract}

Keywords: arduino; irrigation; embedded systems.

\section{Análise de confiabilidade e calibração do sensor de umidade do solo FC-28 montado em plataforma microcontroladora}

\begin{abstract}
RESUMO: Atualmente, a crise hídrica mundial representa um grande desafio à humanidade e um risco a ser gerenciado pelas gerações futuras. De forma a utilizar este recurso de forma consciente, estudos na área de irrigação agrícola apontam a necessidade de se estimar com precisão a quantidade de água a ser usada. Dentre os métodos de determinação da umidade do solo, os sensores, acoplados a um controlador lógico programável, surgem como uma alternativa aos métodos convencionais de laboratório, tornando o procedimento mais rápido e menos trabalhoso. Neste sentido, o presente trabalho avaliou a confiabilidade e precisão de um sensor de baixo custo para determinação da umidade do solo. Um sensor FC-28 associado à uma plataforma Arduino foi usado em três tipos diferentes de solos (texturas: leve, média e pesada), umidades variando de 15 a $50 \%$. Concluiu-se que os sensores avaliados não apresentaram boa precisão para estimar o grau de umidade dos solos. A textura do solo influenciou diretamente as leituras dos sensores, mesmo para a mesma umidade. Além de não apresentaram replicabilidade nem precisão para diferenças menores de $15 \%$ nos valores de umidades. Portanto, é necessário calibrar cada sensor individualmente.

Palavras-chave: arduino; irrigação; plataformas embarcadas.
\end{abstract}

\section{INTRODUCTION}

The World Economic Forum listed the water crisis as the most devastating global risk. Considered an essential component for the preservation of the present and future generations, it is necessary that water is used with increasingly parsimony (ROCCARO; VERLICCHI, 2018; JINDAL et al., 2017). Thus, the design of agricultural production systems that are environmentally and economically sustainable is of paramount importance (PAYERO et al., 2017). For this, an adequate evaluation of soil moisture content is essential to estimate the amount of water to be irrigated during the cultivation of a given crop.
Currently, there are several methods used to determine soil moisture content (at laboratory and field levels), however there is no consensus among the field experts. According to Pouso (2012), the choice of method should consider the objectives desired by the researcher and/or producer, the project or product, the desired precision level, and other factors that may limit their choice. Klar (1988) reports that all methods used to determine soil moisture have limitations: either as their accuracy, or because they are expensive or excessively time-consuming. Libradi (1999) confirms the mentioned limitations and emphasizes the high level of complexity of some methods. 
Within this context, the emergence of faster alternative methods, based on sensors, has been gaining more and more prominence. In general, soil moisture measurement methods using sensors are based on the measurement of soil dielectric properties, which are directly correlated to soil water content around sensor probes (WILL; ROLFES, 2013).

The coupling of a Programmable Logic Controller (PLC) to the soil moisture sensor allows the development of more precise plant cultivation systems, allowing a more efficient and real-time monitoring. The PLC can be used to automate crop irrigation by controlling the water flow to maintain the ideal levels of moisture required for the plant growth (EUSTAQUIO et al., 2016).

In addition, the use of a PLC allows a higher sampling frequency, since measurements can be taken at any time, with no need to go to the field. Another advantage of the use of sensors is the possibility of performing sampling in large areas, requiring only a greater number of sensors connected to a monitoring system through wireless connection.

The soil moisture content sensors model FC-28 have been used in several studies in the last few years, emphasizing the implementation in precision agriculture systems for the monitoring of soil moisture content in agriculture (GADDAM et al., 2014; VANI; RAO, 2016). Some of the key factors for its popularization are its low cost, ease to operate and the possibility of fast data acquisition.

In general, for any type of sensor, its performance and accuracy are important. Studies recommend that universal calibrations provided by sensor manufacturers (if available) should be carefully evaluated in laboratory tests. This is mainly due to the local characteristics where the calibrations of the manufacturers were carried out. Factors such as the presence of plant roots, rocks, climatic conditions and different soil textures directly affect the calibration of the sensors (EVETT et al., 2006; LOGSDON, 2009; RÜDIGER et al., 2010; MITTELBACH et al., 2011).

In this sense, this work aimed to evaluate the reliability and precision of a low-cost soil moisture sensor. For this, the following hypotheses were evaluated: a) Does soil texture influences the sensor reading, which would imply the need to elaborate calibration equations for different soil textures; b) Are there differences within sensors of the same model at a statistical significance, in such a way that it is possible to use a single equation to all sensors of the same model.

\section{MATERIAL AND METHODS}

\subsection{Experimental Site}

The project was developed in the Laboratory of Drainage, Irrigation and Environmental Sanitation (LaDISan) of the Department of Agricultural and Environmental Engineering $\left(\mathrm{TER}^{1}\right)$, located at Praia Vermelha Campus, Fluminense Federal University, NiteróiRJ, Brazil. Located approximately in the geographical coordinates $22.90^{\circ} \mathrm{S} ; 43.13^{\circ} \mathrm{W}$.

\subsection{Programmable Logic Controller}

The Programmable Logic Controller adopted was an Arduino $\mathrm{UNO}^{\circledR}$, with 14 digital data input/output pins (6 of which can be used as PWM output), 6 pins of analog data input/output with a resolution of 10 bits $(\approx 4.9 \mathrm{mV} / \mathrm{bit})$, flash memory (memory for data storage) equal to $32 \mathrm{~KB}$, microcontroller chip ATmega328 and 3.3 or $5.0 \mathrm{~V}$ operating voltage (MOWAD et al., 2014).

\subsection{Sensors and Modules}

In this work, three soil moisture sensors of the model FC28 from Glyduino manufacturer, were used. The FC-28 sensors are composed of 4 pins: a digital communication pin, an analogical communication pin, a VCC (Common Voltage Collector) pin and a common ground pin. This model consists of two parts: a probe composed of two electrodes that remains in direct contact with the soil, and a small module that contains a comparator chip, model LM393, which is responsible for receiving data from the probe, processing and sending it to the microcontroller.

The electrodes are responsible to measure the electric potential difference, caused by the resistance to the electric current flow in the ground. The data obtained are measured in bits (analog values) by the sensor. (KOLAPKAR et al., 2016; RATHORE; SINGH, 2015). The sensor principle of operation is based on the application of an electrical signal, through one of the electrodes of the probe through the ground, which travels through the soil and reaches the second electrode of the probe. The electric potential difference between the applied signal and the one that is received by the second electrode is caused by the resistance of the soil, located between the electrodes of the probe, to the passage of electric current. Therefore, the wetter the soil is, the lower the resistance to the passage of electric current, and vice-versa. In this work, the soil relative humidity data were used to calibrate the sensors and to evaluate their accuracy. In addition, to ease the data acquisition an LCD display model RT162-7 was installed to inform the measured soil moisture content in real-time.

\subsection{Experimental Proceedings}

Three soil types with different textures were used (sandy soil, medium texture soil and clay soil). The granulometric analysis and textural classification of the samples were performed by the pipette method, according to the methodology proposed by EMBRAPA (1997).

Initially, the soil samples were placed in crucibles, and saturated. An air oven model Ethik Technology-404 was used to dehumidify the samples. The experimental design adopted was a $2 \times 2$ factorial with blocking by sensor. There were two factors, being factor A the soil type (sandy, medium and clayey); and factor B the soil moisture content $(15,28,38$ and $52 \%)$; the experimental units were the crucibles, with approximately $300 \mathrm{~g}$ of soil. There were performed 15 replications for each factor-level combination. The randomization rule for a factorial design with blocks was performed and the average waiting time for data acquisition, adopted by the authors, was of $45 \mathrm{~s}$. The samples had their moisture content estimated by the sensors and determined by the standard air oven method (MPUE) at $105 \pm 1{ }^{\circ} \mathrm{C}$ for 48 h (EMBRAPA, 1997). The determination of soil moisture content by means of the MPUE was carried out by the following equation (Equation 1).

$$
\mathrm{U}=\frac{\mathrm{M}_{\mathrm{u}}-\mathrm{M}_{\mathrm{s}}}{\mathrm{M}_{\mathrm{s}}}
$$

${ }^{1}$ http://ter.sites.uff.br/

Nativa, Sinop, v. 9, n. 1, p. 123-128, jan./fev. 2021. 
where: $U=$ percentage of soil moisture ( $\%$, dry basis); $M u=$ mass of the wet sample $(\mathrm{kg}) ; M s=$ mass of the dry sample $(\mathrm{kg})$.

After filtering the data as a function of the mean values obtained by the sensors and the actual reference values, a calibration curve was adjusted for the soil moisture sensor by linear regression, represented in the following equation (Equation 2).

$$
\mathrm{U}_{\mathrm{s}}=\widehat{\beta}_{0}+\widehat{\beta}_{1} \cdot \mathrm{V}
$$

where: $U s=$ percentage of soil moisture determined by the sensor $\left(\%\right.$, dry basis); $V=$ voltage read by the sensor $(V) ; \widehat{\beta}_{0}$ e $\widehat{\beta}_{1}=$ estimated parameters for the calibration equation.

In order to verify the suitability of the proposed model, a residuals plot (residuals vs. fit) analysis was performed, as well as an analysis of residuals normality by the Anderson-Darling test $(\alpha=5 \%)$ and a heteroscedasticity analysis (constancy in variance) using the Breusch-Pagan test $(\alpha=5 \%)$. Inferential statistics were used to obtain a confidence interval for the estimated parameters of the regression equation, with the bands of the regression curve being calculated by the Working-Hotelling coefficient. A two-way ANOVA was performed in order to evaluate the replicability of the sensors and to verify the influence of soil texture on the reading performed by the sensors. For the cases in which a significant difference between the averages was verified ( $F$ test), the Tukey test $(\alpha=5 \%)$ was performed. In order to evaluate whether there was a correlation between the values of moisture content, measured by the sensors, and the values determined by the MPUE, a Pearson correlation was performed. The error of the sensors to estimate the soil's moisture content was evaluated by calculating its root mean square error (RMSE), through the following equation (Equation 3).

$$
\mathrm{RMSE}=\sqrt{\frac{\sum\left(\mathrm{U}_{\mathrm{exp}-\mathrm{U}_{\mathrm{epr}}}\right)^{2}}{\mathrm{~N}}}
$$

where: RMSE = root mean square error; Ue exp $=$ Experimental soil moisture as determined by the MPUE (\%, dry basis); Ue pre = Soil moisture predicted by the sensor calibration curve ( $\%$, dry basis); $N$ $=$ Number of experimental data.

$$
\mathrm{CO}_{2 \mathrm{eq}}=\mathrm{C} \cdot \frac{44}{12}
$$

em que: $\mathrm{CO}_{2 \mathrm{eq}}=$ dióxido de carbono equivalente $\left(\mathrm{Mg} \cdot \mathrm{ha}^{-1} \cdot \mathrm{ano}^{-1}\right) ; \mathrm{C}$ = quantidade de carbono estocado; 44 = massa atômica do $\mathrm{CO}_{2} ; 12$ = massa atômica do C.

\section{RESULTS}

First, the hypothesis that the sensors could present significant difference between each other (replicability) was investigated in order to estimate the percentage of soil moisture. The results are shown in Table 1 .

For all the series of data sampled, sensors 2 and 3 did not present significant statistical difference between each other (Table 1). However, sensor 1 differs from the other sensors in 6 of the 12 analyzed samples.

The results concerning the influence of soil texture on the readings performed by the sensors are presented in Table 2 .
In general, the values read by the sensors differ significantly depending on the soil texture, supporting the initial hypothesis (Table 2). Therefore, in order to use this sensor properly, the user would need to have prior knowledge of the soil type in which the sensor will be installed.

Table 1. Replicability test of the sensors.

Tabela 1. Teste de replicabilidade dos sensores.

\begin{tabular}{cccccc}
\hline \multirow{2}{*}{$\begin{array}{c}\text { Soil } \\
\text { Texture }\end{array}$} & $\begin{array}{c}\text { Soil Water } \\
\text { Content } \\
(\%)\end{array}$ & \multicolumn{3}{c}{$\begin{array}{c}\text { Average Sensor Voltage } \\
(\mathrm{V})\end{array}$} & $\begin{array}{c}\text { p- } \\
\text { value }\end{array}$ \\
\cline { 3 - 5 } Sandy & 15 & S1 & S2 & S3 & \\
\hline \multirow{4}{*}{ Medium } & 28 & 2,42 & 2,38 & 2,39 & 0,624 \\
& 38 & 4,85 & $2,21 \mathrm{~b}$ & $2,11 \mathrm{~b}$ & $7 \times 10^{-7}$ \\
& 52 & 5,00 & 5,00 & 5,61 & 0,160 \\
& 15 & 1,89 & 1,90 & 1,89 & - \\
& 28 & $2,86 \mathrm{c}$ & $2,35 \mathrm{~d}$ & $2,38 \mathrm{~d}$ & 0,000 \\
& 38 & $3,93 \mathrm{c}$ & $3,67 \mathrm{~d}$ & $3,68 \mathrm{~d}$ & 0,008 \\
Clay & 52 & 5,00 & 5,00 & 5,00 & - \\
& 15 & $1,40 \mathrm{e}$ & $1,51 \mathrm{f}$ & $1,52 \mathrm{f}$ & 0,006 \\
& 28 & $2,51 \mathrm{e}$ & $1,94 \mathrm{f}$ & $1,93 \mathrm{f}$ & 0,000 \\
& 38 & $4,69 \mathrm{e}$ & $4,17 \mathrm{f}$ & $4,12 \mathrm{f}$ & 0,013 \\
& 52 & 4,99 & 4,99 & 4,99 & 0,244 \\
\hline
\end{tabular}

Means followed by the same letter in the line do not differ significantly at the $5 \%$ level by the Tukey test, "-" indicates that there was no variation in the replications of each mean.

Table 2. Evaluation of soil texture influence in the readings performed by the sensors.

\begin{tabular}{|c|c|c|c|c|c|}
\hline \multirow[b]{2}{*}{ Sensor } & \multirow{2}{*}{$\begin{array}{c}\text { Soil Water } \\
\text { Content } \\
(\%)\end{array}$} & \multicolumn{3}{|c|}{ Average Sensor Voltage (V) } & \multirow[b]{2}{*}{$\mathrm{p}$-valor } \\
\hline & & $\begin{array}{c}\text { Sandy } \\
\text { soil }\end{array}$ & $\begin{array}{c}\text { Medium } \\
\text { texture soil }\end{array}$ & $\begin{array}{c}\text { Clayey } \\
\text { soil }\end{array}$ & \\
\hline S1 & & $2,42 \mathrm{a}$ & $1,89 \mathrm{~b}$ & $1,40 \mathrm{c}$ & $1,7 \times 10^{-}$ \\
\hline S2 & 15 & $2,38 \mathrm{a}$ & $1,90 \mathrm{~b}$ & $1,51 \mathrm{c}$ & $2,9 \times 10-$ \\
\hline S3 & & $2,39 a$ & $1,89 \mathrm{~b}$ & $1,52 \mathrm{c}$ & $1,8 \times 10^{-}$ \\
\hline S1 & & $2,97 d$ & 2,86de & $2,51 \mathrm{e}$ & 0,040 \\
\hline S2 & 28 & $2,21 \mathrm{de}$ & $2,35 d$ & $1,94 \mathrm{e}$ & 0,010 \\
\hline S3 & & 2,11de & $2,38 \mathrm{~d}$ & $1,93 \mathrm{e}$ & 0,004 \\
\hline S1 & & $4,85 f$ & $3,93 \mathrm{~g}$ & $4,69 \mathrm{f}$ & $1,4 \times 10^{-}$ \\
\hline S2 & 38 & $4,65 f$ & $3,67 \mathrm{~g}$ & $4,17 \mathrm{~h}$ & $1,4 \times 10^{-6}$ \\
\hline S3 & & $4,61 \mathrm{f}$ & $3,68 \mathrm{~g}$ & $4,12 \mathrm{~h}$ & $1,1 \times 10^{-5}$ \\
\hline S1 & & $5,00 \mathrm{i}$ & $5,00 \mathrm{i}$ & $4,99 j$ & $4,6 \times 10^{-9}$ \\
\hline S2 & 52 & $5,00 \mathrm{i}$ & $5,00 \mathrm{i}$ & $4,99 j$ & $1,2 \times 10^{-}$ \\
\hline S3 & & $5,00 \mathrm{i}$ & $5,00 \mathrm{i}$ & $4,99 j$ & $3,55 \times 10^{-}$ \\
\hline
\end{tabular}

Tabela 2. Avaliação da influência da textura do solo nas leituras realizadas pelos sensores.

Means followed by the same letter in the line did not differ significantly at the $5 \%$ level by the Tukey test.

\subsection{Sensors Calibration}

The results of the correlation between the values read by the sensors and the values determined by the MPUE are presented in Table 3.

The voltage values measured by the sensors and the values determined by the MPUE were classified as very strong correlation $(-1.0<\mathrm{r}<0.90$ or $0.90<\mathrm{r}<1.0)$ according to the classification proposed by Hinkle et al. al. (2003). The values in parentheses ( $\mathrm{p}$-value) located below the values of the correlation coefficient indicated that all correlations were significant by the $\mathrm{t}$ test $(\mathrm{p}<0.05)$, proving that there is a strong correlation between the values measured by the sensor and the expected moisture content of the soil. 
Table 3. Correlation between the values read by the sensors and the values determined by the MPUE.

Tabela 3. Correlação entre os valores lidos pelos sensores e os valores determinados pelo MPUE.

\begin{tabular}{llll}
\hline \multirow{2}{*}{ Soil texture } & \multicolumn{3}{c}{ Sensor readings and MPUE Correlation } \\
\cline { 2 - 4 } & \multicolumn{1}{c}{$/$ Sensor 1 } & Sensor 2 & Sensor 3 \\
\cline { 2 - 4 } Sandy Soil & $-0,9348$ & $-0,9348$ & $-0,9366$ \\
\multirow{2}{*}{ Medium } & $(0,0198)$ & $(0,0189)$ & $(0,0190)$ \\
Texture Soil & $-0,9865$ & $-0,9638$ & $-0,9652$ \\
\multirow{2}{*}{ Clayey Soil } & $(0,0003)$ & $(0,0019)$ & $(0,0018)$ \\
& $-0,9588$ & $-0,9600$ & $-0,9608$ \\
& $(0,0025)$ & $(0,0024)$ & $(0,0023)$ \\
\hline
\end{tabular}

To evaluate the goodness of fit, three different calibrations were performed, considering the voltage values measured by the sensors and the soil texture. The mean voltage values measured by the sensors were plotted together with their respective values of moisture content, determined by the standard official methodology in Brazil for the determination of the moisture content, the results are presented in Figure 1.

It can be seen from Table 4 that all soil types presented a negative slope for regression $\left(\beta_{1}\right)$, which confirms the results obtained previously. In addition, constant variance ( $\mathrm{p}$-value $>$ $\alpha$ ) of the sample residuals was observed by the Breush-Pagan test, indicating the adequacy of the adopted model. The normality assumption was not met for any type of soil ( $\mathrm{p}$ value $>\alpha)$, however, as the size of the sample data is relatively large (60 samples), this is not an issue according to the central limit theorem (KUTNER et al., 2004).

Table 4. Summary of regression data and statistical parameters.

Tabela 4. Resumo dos dados da regressão e parâmetros estatísticos.

\begin{tabular}{cccc}
\hline $\begin{array}{c}\text { Parameters/Soil } \\
\text { type }\end{array}$ & $\begin{array}{c}\text { Sandy } \\
\text { Soil }\end{array}$ & $\begin{array}{c}\text { Medium Texture } \\
\text { Soil }\end{array}$ & Clay Soil \\
& $\begin{array}{c}6.753 \leq \\
\beta_{0} \leq\end{array}$ & $\begin{array}{c}5.249 \leq \beta_{0} \leq \\
\text { Intercept } \\
7.727\end{array}$ & $\begin{array}{c}5.915 \\
\beta_{0} \leq\end{array}$ \\
& $-0.145 \leq$ & & 6.919 \\
& $\beta_{1} \leq-$ & $-0.077 \leq \beta_{1} \leq-$ & $-0.099 \leq$ \\
& 0.116 & 0.062 & 0.082 \\
Slope & 0.841 & 0.858 & 0.872 \\
R 2 & 0.665 & 0.516 & 0.556 \\
RMSE & & & \\
Anderson- & $<0.05$ & $<0.05$ & $<0.05$ \\
$\begin{array}{c}\text { Darling test (p- } \\
\text { value) }\end{array}$ & & & \\
Breush-Pagan & 0.264 & 0.2816 & 0.0818 \\
test (p-value) & & & \\
\hline
\end{tabular}

\section{DISCUSSION}

Sharma et al. (2017) verified that soil moisture sensors with resistance-based functioning can be impaired when tested on soils with different texture, physical and chemical characteristics, which explains the results found in this work.

Based on the data displayed at table 1, when looking within the same texture, for sand $28 \%$ had two readings equal but different for A1; at medium texture $\mathrm{S} 1$ kept this behavior, adding that S2 and S3 were unable to differ 29 to $38 \%$ moistures (neither S1). At clay soil S1 had no voltage variation at any moisture, same behavior for S2 and S3 but at different levels.

This information could indicate the presence of a systematic error, probably due to manufacture process unable to give all sensors the same features, from what adopting a single global calibration is not recommended for the sensors.
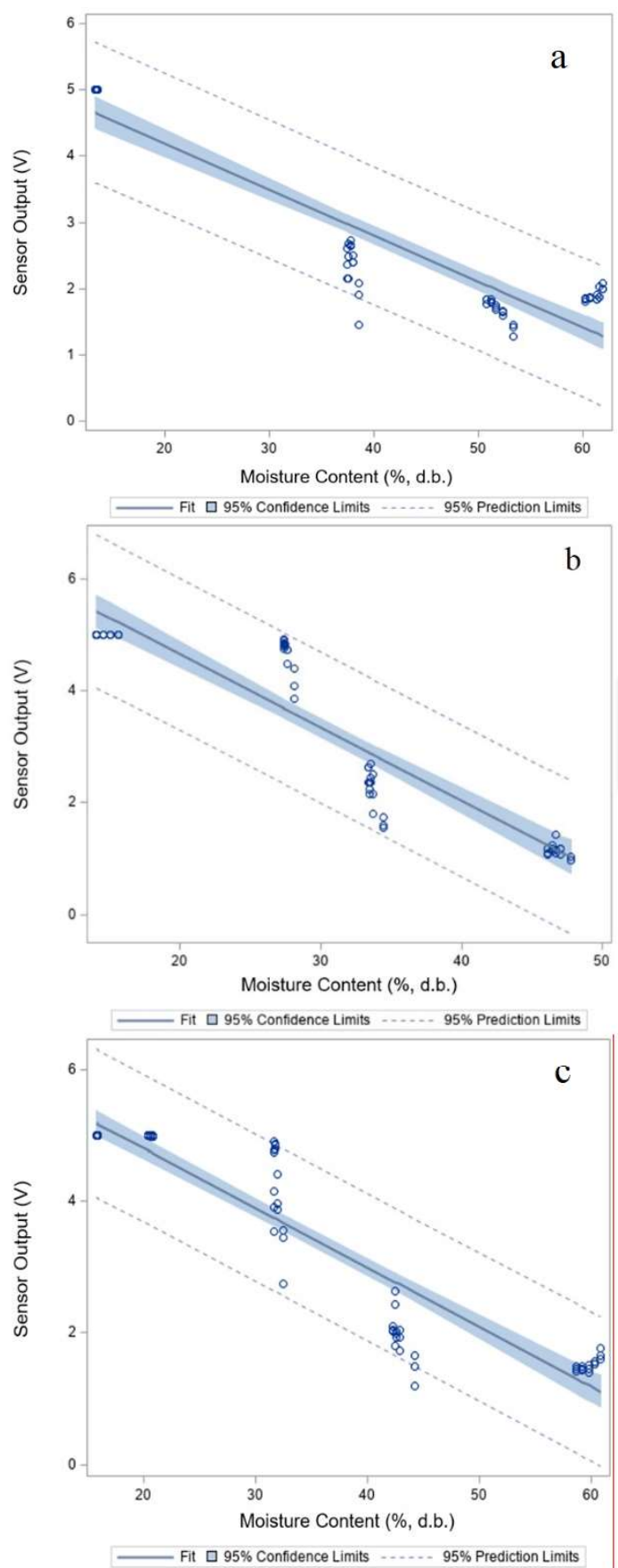

Figure 1. Sensors calibration for soils of sandy texture (a), medium texture (b) and clay texture (c).

Figura 1. Calibração dos sensores para solos de textura arenosa (a), textura média (b) e textura argilosa (c).

Therefore, it is necessary an individual calibration for each sensor, otherwise it would not be possible to count with moisture measurement with less them $10 \%$ threshold, as they would be statically equal $(\mathrm{p}<0.05)$, and this could be higher depending on the soil texture. 
For table 2, grouping sensor readings by moisture level (where was expected to have reading not differing within the same moisture, regardless the soil texture); all three sensors were able to read 15\% moisture for all three textures (did not differ significantly), but at different voltage for each texture, indicating that even when they translate well the moisture (into voltage), the use of a single calibration model disregarding the soil texture, is a mistake.

As the moisture rises, the sensors' readings decrease the differences within texture but kept the difference between moisture, as with $52 \%$ they were able to have the same reading for sand and medium texture, but not for clay. Thus, the sensor could have a suitable performance, once calibrated to the soil.

When calibrating and building the model, it was verified that the voltage values presented an inverse relation to the soil moisture, which was already expected, since low voltage values are associated with low values of resistance to the passage of electric current in the soil. Results obtained by Vernandhes et al. (2017) corroborated this finding.

The $\mathrm{R}^{2}$ values obtained by the calibration curves ( 0.841 , 0.858 and 0.872 ) indicated an efficient calibration, validating the calibration of these sensors. PAYERO et al. (2017), using Decagon EC-5 model soil moisture sensors, which have a working principle based on the measurement of soil dielectric constant using capacitance technology, performed the calibration for a soil type, resulting in equal $\mathrm{R}^{2}$ to 0.999 . A similar result was found for the $\mathrm{R}^{2}$ of the calibration equation, which uses the mean values obtained by the sensors.

The RMSE values for the sensors were 0.665; 0.516; and 0.556 for sandy, medium texture and clay soils, respectively. The values found were relatively high, as there are commercial sensors with errors lower than $3 \%$, such as the Fieldscout 350 TDR probe (manufacturer Spectrum Technologies, Inc.). Such results cast doubt on the accuracy and reliability of the sensors studied in this work.

Therefore, the use of sensors should be restricted to operations that do not require high accuracy (i.e. lower than $10 \%$ ). In addition, the sensors should not be used in experiments that require data acquisition in several locations at the same time, since this procedure requires individual calibration, which would make the procedure extremely time consuming.

\section{CONCLUSIONS}

The evaluated sensors did not present good precision to estimate soil moisture content without previous calibration procedure.

Soil texture directly influenced the readings obtained by the sensors at a given value of moisture content, so - once calibrated for the soil texture - more accurate measurements could be expected.

Low and dry soils led to a better sensor performance (above 50\% moisture conditions). Therefore, it's important to have a prior knowledge of the soil type in which the sensor will be used. The lack of information can lead to misleading information, resulting in waste of resources or an inefficient irrigation.

The evaluated sensors did not present replicability, so it is necessary to calibrate each sensor individually. Therefore, the use of this sensor model for monitoring soil conditions in larger areas is not feasible (due to soil texture variation and large moisture range).
Despite its low cost, flexibility and fast data acquisition, this sensor model requires a time-consuming calibration procedure.

\section{ACKNOLEDGEMENT}

The authors thank Professor Dario de Andrade Prata Filho for allowing the use of the LaDISan laboratory where the experiment was developed and for his aid to the research. The authors would like to thank the research funding agencies CAPES and FAPEMIG for the scholarships granted to the post-graduate students participating in the study.

\section{REFERENCES}

EMBRAPA_Empresa Brasileira de Pesquisa Agropecuária. Centro Nacional de Pesquisa de Solo. Manual de métodos de análise de solo. 2 ed. Rio de Janeiro. Embrapa Solos, 1997. 212p.

EUSTAQUIO, J. F. L. L.; SANTANA, G. M.; SILVA, E. L. L.; ALEMÃO, P.; VASCONCELOS, L. C. L.; SILVA, M. E. O.; PONTES, P. M.; SILVA, T. F. L. Construção e desenvolvimento de um sensor de umidade de solos utilizando Arduino. Jaboatão/PE: Fundação Bradesco, 2016. 4p. Disponível em: http://sistemaolimpo.org/midias/uploads/c85c65e0c68 fcaf7e6ccdfbbd7e847e5.pdf. Acesso em: 25 fev. 2021.

EVETT, S. R.; TOLK, J. A.; HOWELL, T. A. Soil profile water content determination: Sensor accuracy, axial response, calibration, temperature dependence, and precision. Vadose Zone Journal, v. 5, n. 3, p. 894-907, 2006. DOI: $10.2136 /$ VZJ2005.0149

GADDAM, A.; AL-HROOBY, M.; ESMAEL, W. F. Designing a wireless sensors network for monitoring and predicting droughts. In: International Conference on Sensing Technology, $8^{\text {th }}$. Proceedings... Liverpool, U.K. 2014.

GHI_ Global Harvest Initiative. Global Agricultural Productivity Report. 2017. 72p.

HINKLE, D. E.; WIERSMA, W.; JURS, S. G. Applied Statistics for the Behavioral Sciences. 5th ed. Boston: Houghton Mifflin, 2003. 792p.

JINDAL, H.; SAXENA, S.; KASANA, S. S. Sewage water quality monitoring framework using multi-parametric sensors. Wireless Personal Communications, v. 97, n. 1, p. 881-913, $2017 . \quad$ DOI: https://doi.org/10.1007/s11277-017-4542-3

KLAR, A. E. Água no sistema. 2 ed. São Paulo: Nobel, 1988. 408p.

KOLAPKAR, M. M.; KHIRADE, P. W.; SAYYAD, S. B. Design and development of embedded system for measurement of humidity, soil moisture and temperature in polyhouse using 89e516rd microcontroller. International Journal of Advanced Agricultural Science and Technology, v. 5, n. 1, p. 96110, 2016.

KUTNER, M. H.; NACHTSHEIM, C.J.; NETER, J.; LI, W. Applied linear statistical models. 5 ed. New York, NY: McGraw-Hill Higher Education, 2004. 1424p.

LIBARDI, P. L. Dinâmica da água no Solo. Piracicaba: Ed. do Autor, 1999. 497p.

LOGSDON, S. D. CS616 Calibration: Field versus Laboratory. Soil Science Society of America Journal. v. 73, n. 1, p. 1-6, 2009. DOI: 
https://doi.org/10.2136/sssaj2008.0146

MCROBERTS, M. Beginning Arduino. 1 ed. New York, NY: Apress Inc., 2010. 475p.

MITTELBACH, H.; CASINI, F.; LEHNER, I.; TEULING, A. J.; SENEVIRATNE, S. I. Soil moisture monitoring for climate research: evaluation of a low-cost sensor in the framework of the swiss soil moisture experiment (SwissSMEX) campaign. Journal of Geophysical Research -Atmosphere, v. 116, n. 11, D05111, 2011. DOI: https://doi.org/10.1029/2010JD014907

MOWAD, M. A. E. L.; FATHY, A.; HAFEZ, A. Smart home automated control system using android application and microcontroller. International Journal of Scientific \& Engineering Research, v. 5, n. 5, p. 935-939, 2014.

PAYERO, J. O.; NAFCHI, A. M.; DAVIS, R.; KHALILIAN, A. An Arduino-Based Wireless Sensor Network for Soil Moisture Monitoring Using Decagon EC-5 Sensors. Open Journal of Soil Science, v. 7, n. 10, p. 288, 2017. DOI: 10.4236/ojss.2017.710021

POUSO, M. T. P. Sistema de automação e controle de um sistema de irrigação. Brasília: UniCEUB, 2012. 85p.

RATHORE, J.; SINGH, J. Review on Wireless Sensor System using Zigbee for Greenhouse. International Journal of Engineering and Management Research, v. 5, n. 6, p. 73-76, 2015.

ROCCARO, P.; VERLICCHI, P. Wastewater and reuse. Current Opinion in Environmental Science \& Health, v. 2, p. 61-63, 2018. DOI: 10.1016/j.coesh.2018.03.008

RÜDIGER, C.; WESTERN, A. W.; WALKER, J. P.; SMITH, A. B.; KALMA, J. D.; WILLGOOSE, G. R. Towards a general equation for frequency domain reflectometers. Journal of Hydrology, v. 383, n. 3-4, p. 319-329, 2010.2 DOI: https://doi.org/10.1016/j.jhydrol.2009.12.046

SHARMA, H.; SHUKLA, M. K.; BOSLAND, P. W.; STEINER, R. Soil moisture sensor calibration, actual evapotranspiration, and crop coefficients for drip irrigated greenhouse chile peppers. Agricultural Water Management, v. 179, p. 81-91, 2017. DOI: https://doi.org/10.1016/j.agwat.2016.07.001

VANI, P. D.; RAO, K. Measurement and monitoring of soil moisture using cloud IoT and android system. Indian Journal of Science and Technology, v. 9, n. 31, p. 1-9, 2016. DOI: $10.17485 / \mathrm{ijst} / 2016 / v 9 \mathrm{i} 31 / 95340$

VERNANDHES, W.; SALAHUDDIN, N. S.; KOWANDA, A.; SARI, S. P. Smart aquaponic with monitoring and control system based on iot. In: Informatics and Computing (ICIC) and Second International Conference on IEEE. Proceedings... p. 1-6, 2017. Available in: https://ieeexplore.ieee.org/document/8280590

WILL, B.; ROLFES, I. Comparative study of moisture measurements by time domain transmissometry. In: SENSORS, IEEE. Proceedings... Baltimore, MD, USA, 2013. Available in: https://ieeexplore.ieee.org/abstract/document/ 668852 9 